\title{
DIRT AND ABSORPTION TESTS IN PROTECTIVES FILMES APPLIED TO PHOTOVOLTAIC PANELS: A SYSTEMATIC REVIEW.
}

\section{Luciano Teixeira dos Santos, lucianoteixeira@ifba.edu.br ${ }^{1}$}

Alex Álisson Bandeira Santos, alex.santos@fieb.org.br¹

Joyce Batista Azevedo, Joyce.azevedo@ufrb.edu.br²

Paulo Roberto Freitas Neves, paulo.neves@fieb.org.br²

1 Faculdade de Tecnologia SENAI CIMATEC, Av. Orlando Gomes, 1875, Piatã, Salvador - BA.

2 Universidade Federal do Recôncavo da Bahia, Av. Centenário, 687, SIM, Feira de Santana - BA.

3 Instituto Federal de Educação, Ciência e Tecnologia da Bahia, Av. São Cristóvão,s $/ \mathrm{n}^{\circ}$, Itinga, Lauro de Freitas - BA.

\begin{abstract}
To mitigate the loss of efficiency of photovoltaic modules, protective films of polyethylene terephthalate with tin doped indium oxide (PET / ITO) may be a viable alternative. Thus, the article presents a review on the effect of the accumulation of dirt in photovoltaic modules and on the state of the art involving protective films made of PET / ITO. The review started in 2019 with a predominance of articles published abroad and in international journals. The results show that there are several studies on the effect of dirt on photovoltaic systems, but these are studies that do not take into account the comparison between studies done in the laboratory and in adverse conditions of the external environment such as rain, wind and film degradation.
\end{abstract}

Keyword: PET / ITO films; Solar Panel; Efficiency; Dirt. 


\section{ENSAIOS SOBRE SUJIDADE E ABSORÇÃO EM FILMES PROTETIVOS APLICADOS A PAINÉIS FOTOVOLTAICOS: UMA REVISÃO SISTEMÁTICA.}

Resumo: Para atenuar a perda de eficiência de módulos fotovoltaicos os filmes protetivos de politereftalato de etileno com óxido de índio dopado com estanho (PET/ITO) podem ser uma alternativa viável. Sendo assim o artigo apresenta uma revisão sobre o efeito do acúmulo de sujidade em módulos fotovoltaicos e sobre o estado da arte que envolve filmes protetivos feitos de PET/ITO. A revisão foi iniciada no ano de 2019 com predominância de artigos publicados no exterior e em revistas internacionais. Os resultados mostram que existem diversos estudos sobre o efeito da sujidade nos sistemas fotovoltaicos, mas se tratam de estudos que não levam em consideração a comparação entre estudos feitos em laboratório e em condições adversas do meio externo como chuva, vento e degradação do filme.

Palavras-chave: Filmes PET/ITO, Painel Solar, Eficiência, Sujidade. 


\section{INTRODUCTION}

The use of solar energy for the generation of electrical energy brings benefits to its users, as it generates credit on the electric bill, causing a reduction in the invoice and providing a worthwhile investment in 3 years. It is known that on average, photovoltaic modules (PV) have a useful life 25 years, that is, for 22 years consumers take advantage of their benefits. With a relatively large list of benefits, solar energy photovoltaic will probably be considered larger than any other renewable technology in the near future. The main advantages of energy can be related to its use, since it is considered a primary source of constant, free and relatively inexhaustible energy [1]. When doing a more detailed analysis, it is noticed that in some cases a return on investment occurs from the first 4 years of a long useful life [2]. This makes your equipment and installation are paid well before their "expiration date" through this economy. No other source of energy has grown as photovoltaic solar system in the recent past. Between the years 2010 and 2016 the solar energy presented an average annual growth of $40 \%$, jumping from installed power from less than $50 \mathrm{GW}$ in 2010 to more than $320 \mathrm{GW}$ in the end of 2016 [3].

Dirt on the surface of PV modules is a growing concern due to decreased electricity production from a solar installation photovoltaic. What has happened is that the expansion of solar markets is growing in desert areas and also in large metropolises, areas that not only have the greatest availability of solar resources, but also also the most critical dirt problems, as the PV modules are more exposed to dust in these mentioned areas [4]. The dust that is deposited on the photovoltaic generator can present different aspects, varying in relation to the locality. In the case of centers urban areas, the carbon composition is remarkable, due to vehicle emissions automotive, presenting sticky texture, which adheres to the surface of the module [4].

In such cases, even with maintenance measures for cleaning the modules, it is difficult to remove this type of dirt. Besides that, even in cases where the system is installed in remote regions, remote from urban centers, the installation can be in a place of difficult access, preventing periodic cleaning [4]. Therefore, the way the problem works, the understanding and mitigation are important factors to avoid any misunderstanding in the dimensioning and implantation of a solar installation. The problem of dirt is not limited to areas of severe climate, but also losses significant differences can be found in areas with tropical environments and tempered [4]. It is necessary to highlight that the Northeast of Brazil has great potential related to the generation of electric energy from solar energy. This happens, due to the fact that much of the territory comprising this region is located in a range where the incidence of ultraviolet rays reaches one of thehighest levels in the world during the year [5]. Compared to countries like Spain and Germany, Brazil, especially the Northeast region, presents high values of global solar irradiation. So it is It is necessary to explore this potential of the Brazilian Northeast in order to plan and find ways to encourage solar technology in this region by providing economic development and contributing to an energy matrix more sustainable [5].

Therefore, it is clear that the Northeast of Brazil presents a great potential in terms of solar resource. However, this region of Brazil is still there is a need for studies that analyze local aspects, as the influence of climate and environmental characteristics can cause different impacts, which are peculiar to the region, in the performance of a PV module [4]. 


\section{METHODOLOGY}

The methodology aims to build a systematic review of work works that deal with protective films applied to photovoltaic panels to increase performance. The study carried out considered the research sources listed in Table 1 right after.

Table 1. Research sources used for the selection of publications.

\begin{tabular}{|c|}
\hline RESEARCH SOURCES USED \\
\hline Science Direct \\
\hline Capes Journals \\
\hline Academic Google \\
\hline
\end{tabular}

For the Science Direct research source, the keywords were added in english to obtain the articles. The selection of publications that started on 10/30/2019 and considered the period from october 2019 until the beginning of 2020. The analysis of the publications identified was carried out according to the phases defined in Figure 3.3 immediately afterwards.

Figure 1. Phases of inclusion, exclusion and prioritization of scientific articles.

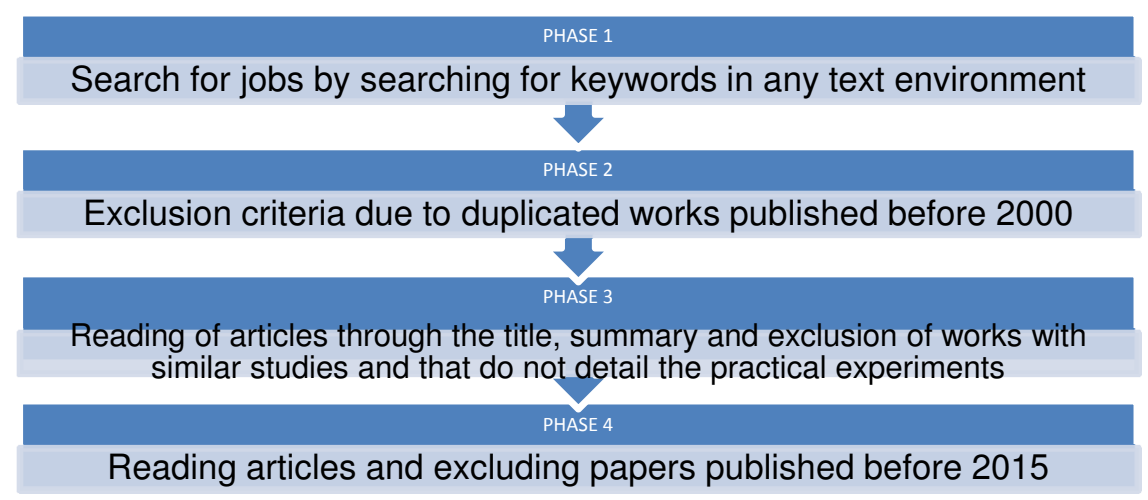

As shown in Figure 1, Phases 1, 2 and 3 determine the inclusion or exclusion criteria and Phase 4 determines the prioritization, exclusion and selection criteria for articles classified after Phase 3 . The results of the selection of publications, after the the phases defined in Figure 1 are shown in Table 2 below.

Table 2. Result of the selection of publications, after performing the Phases.

\begin{tabular}{|c|c|c|c|c|}
\hline SOURCES & PHASE 1 & PHASE 2 & PHASE 3 & PHASE 4 \\
\hline Science Direct & 153 & 137 & 57 & 17 \\
\hline Capes Journals & 4 & 0 & 0 & 0 \\
\hline Academic Google & 13 & 0 & 0 & 0 \\
\hline
\end{tabular}

The qualitative analysis of the selected works that reached Phase 4 was performed based on the answers to pre-determined questions $(P)$, attributing the answers "Yes (value 1)", "Partial (value 0.5)" and "No (value 0) ". Therefore, the higher the value of the selected article, the more it is aligned and relevant to the research content. The questions selected for the study were:

P1: Is an analysis carried out on the reduction of dirt deposition on the photovoltaic module? module?

P2: Is a method applied to mitigate the loss of efficiency of the photovoltaic 

evaluated?

P3: In the applied method, is a polymeric film used and its degradation

\section{RESULTS AND DISCUSSION}

The result of the selection of publications after Phase 4 shows that, to date, a total of 17 articles have been prioritized, all from the research source Science Direct. Table 3, right after, represents the result of the selection of publications for the proposed study.

Table 3. Prioritization of articles after the criteria defined in Phase 4.

\begin{tabular}{|c|c|c|c|c|c|c|}
\hline \multirow{2}{*}{$\mathbf{N}^{\circ}$} & \multirow{2}{*}{ TITLE OF THE ARTICLE } & \multicolumn{4}{|c|}{ QUESTIONS } & \multirow{2}{*}{ REFERENCE } \\
\hline & & P1 & $\mathbf{P 2}$ & $\mathbf{P}_{3}$ & Total & \\
\hline 1 & $\begin{array}{l}\text { Indium-tin oxide thin films deposited at room temperature on glass } \\
\text { and PET substrates: Optical and electrical properties variation } \\
\text { with the } \mathrm{H}_{2}-\text { Ar sputtering gas mixture. }\end{array}$ & 0 & 0,5 & 0 & 0,5 & [6] \\
\hline 2 & $\begin{array}{l}\text { An all-thinfilm inorganic electrochromic device monolithically } \\
\text { fabricated on flexible PET/ITO substrate by magnetron } \\
\text { sputtering. }\end{array}$ & 0 & 0,5 & 0 & 0,5 & [7] \\
\hline 3 & $\begin{array}{l}\text { ITO and AZO films for low emissivity coatings in hybrid } \\
\text { photovoltaic-thermal applications. }\end{array}$ & 0,5 & 0,5 & 0 & 1 & [8] \\
\hline 4 & $\begin{array}{l}\text { Technical and economic assessment of cleaning protocol for } \\
\text { photovoltaic power plants: Case of Algerian Sahara sites. }\end{array}$ & 0,5 & 1 & 0 & 1,5 & [9] \\
\hline 5 & $\begin{array}{l}\text { Na integrated review of factors influencing the performance } \\
\text { of photovoltaic panels. }\end{array}$ & 0,5 & 1 & 0 & 1,5 & [10] \\
\hline 6 & $\begin{array}{l}\text { Experimental study of factors affecting dust accumulation and their } \\
\text { effects on the transmission coefficient of glass for solar } \\
\text { applications. }\end{array}$ & 1 & 0,5 & 0 & 1,5 & [11] \\
\hline 7 & $\begin{array}{l}\text { Experimental evaluation of the performance and degradation of } \\
\text { single crystalline silicon photovoltaic modules in the Saharan } \\
\text { environment }\end{array}$ & 0,5 & 0 & 0 & 0,5 & [12] \\
\hline 8 & $\begin{array}{l}\text { Reducing the effect of dust deposition on the generating } \\
\text { efficiency of solar PV modules by super-hydrophobic films. }\end{array}$ & 1 & 1 & 0 & 2 & [13] \\
\hline 9 & $\begin{array}{l}\text { The effect of environmental factors and dust accumulation on } \\
\text { photovoltaic modules and dust-accumulation mitigation strategies. }\end{array}$ & 1 & 0,5 & 0 & 1,5 & [14] \\
\hline 10 & $\begin{array}{l}\text { Low temperature sputtered ITO on glass and epoxy resin } \\
\text { substrates: influence of process parameters and substrate } \\
\text { roughness on } 33 \text { morphological and electrical properties. }\end{array}$ & 0,5 & 0 & 0 & 0,5 & [15] \\
\hline 11 & $\begin{array}{l}\text { Experimental Study on the Effect of Dust Deposition on } \\
\text { Photovoltaic Panels. }\end{array}$ & 1 & 0,5 & 0 & 1,5 & [16] \\
\hline 12 & The Controllable Deposition Of Large Area Roll-To-Roll & 0 & 0,5 & 0 & 0,5 & [17] \\
\hline
\end{tabular}




\begin{tabular}{|c|c|c|c|c|c|c|}
\hline & Sputtered Ito Thın Films For Photovoltaıc Applıcatıons. & & & & & \\
\hline 13 & $\begin{array}{l}\text { 13.5\% flexible organic solar cells achieved by robust } \\
\text { composite ITO/PEDOT:PSS electrodes. }\end{array}$ & 0 & 0,5 & 0 & 0,5 & [18] \\
\hline 14 & $\begin{array}{l}\text { Measuring factors influencing performance of rooftop } \mathrm{PV} \\
\text { panels in warm tropical climates. }\end{array}$ & 0,5 & 0,5 & 0 & 1 & [19] \\
\hline 15 & $\begin{array}{l}\text { Cost effective cooling of photovoltaic modules to improve } \\
\text { efficiency. Case Studies in Thermal Engineering. }\end{array}$ & 0 & 0,5 & 0 & 0,5 & [20] \\
\hline 16 & $\begin{array}{l}\text { A review of anti-reflection and selfcleaning coatings on } \\
\text { photovoltaic panels. }\end{array}$ & 0,5 & 0,5 & 0 & 1 & [21] \\
\hline 17 & $\begin{array}{l}\text { Dust Deposition can Focus Light at a Limited Distance on } \\
\text { Photovoltaic Panels. }\end{array}$ & 0,5 & 1 & 0 & 1,5 & [22] \\
\hline
\end{tabular}

Among the seventeen articles that are in line with the proposed research, three articles can be highlighted for this work, which will be summarized shortly thereafter. In [22] a study of the effect of focus light on photovoltaic cells is carried out to reduce the negative effect of particle deposition. One of the results shows that the received solar radiation was 10 times more intense than in the direct form, which can be obtained from the effect of focusing light on the deposition of particles. In addition, some special coating structures can be designed to exploit this valuable effect in order to manufacture more efficient modules.

The article proposed in [13] studied the effect of dust deposition on the efficiency of generating PV modules by superhydrophobic films. The films based on fluorine and silicon were compared, evaluating the effect of dust deposition on PV coated with superhydrophobic films and how they act on the efficiency of generating photovoltaic panels. Fluorine-based films showed better results and the authors found that super-hydrophobic films can reduce the accumulation of dirt and improve the conversion efficiency of photovoltaic modules. However, despite this, the study did not analyze the effect of film degradation on the performance of photovoltaic modules.

The authors of [16] carried out an evaluation of the performance of solar cells under the effect of dirt. The proposed method for depositing dirt was based on dust densities, which varied from $10 \mathrm{~g} / \mathrm{m}^{2}, 20 \mathrm{~g} / \mathrm{m}^{2}$ and $30 \mathrm{~g} / \mathrm{m}^{2}$. The field results show that the increase in dust density causes a decrease in the electrical parameters of the photovoltaic cell, interfering with its performance. Importantly, the study shows that when the density of the powder reaches a certain degree of concentration, the conversion efficiency tends to be stable and very similar to a saturation phenomenon.

\section{CONCLUSION}

As can be seen from the results in Table 3 , the theme in question this issue has been increasingly object of interest to researchers. At the however, the analysis in Table 3 also shows that no publications that carried out tests on dirt and absorption of PV modules with the application of PET / ITO films and neither evaluated their degradation. This can be seen by observing that none of the selected 
articles fitted with question P3, demonstrating the originality of the proposed theme. It is worth noting that the selection of these publications makes a contribution to the formulation of the state of the art of this study, which can serve as a contribution and aid to other studies involving the proposed theme.

\section{Acknowledgments} provided.

The authors would like to thank SENAI CIMATEC for the technological support

\section{REFERENCES}

${ }^{1}$ SANTOS, P.; SILVA, C.M.G. Estudo da Expansão da Energia Solar Fotovoltaica no Brasil: benefícios ambientais e incentivos públicos. $1^{\circ}$ Congresso de Inovação, Ciência e Tecnologia do IFSP, 2019.

2 KALINE, C.; CARVALHO, E.K.S.; BARBOSA, L.T.; SANTOS, G.F.A. Uso da energia solar fotovoltaica como alternativa de economia e sustentabilidade:estudo de caso em residência em Palmas - TO. Congresso Técnico e Científico da Engenharia e da Agronomia, Palmas - TO, 2019.

3 FRAUNHOFER, Institute for Solar Energy Systems, ISE. Photovoltaics Report. Relatorio tecnico. Disponivel em: www.ise.fraunhofer.de. Acessado em 19 de abril de 2020.

4 HICKEL, B.; DESCHAMPS, E.; NASCIMENTO, L.; RUTHER, R.; SIMÕES, G. Análise do acúmulo de sujeira sobre diferentes tecnologias de módulos FV: revisão e medições de campo. VI Congresso Brasileiro de Energia Solar. Belo Horizonte, 2016.

${ }^{5}$ NASCIMENTO, A. Energia Folar Fotovoltaica: Estudo e Viabilidade no Nordeste Brasileiro. Dissertação de Mestrado em Engenharia de Produção. Universidade Federal da Paraíba. João Pessoa - PB, 2015.

6 ÁlVAREZ, Fraga; VILLACORTA, Jiménez; MARCOS, Sánchez; ANDRÉS, A.; PRIETO, C. Indium-tin oxide thin films deposited at room temperature on glass and PET substrates: Optical and electrical properties variation with the $\mathrm{H} 2-$ Ar sputtering gas mixture. Applied Surface Science, v. 344, p. 217-222, 2015.

7 LIU, Q.; DONG, G.; XIAO, Y.; GAO, F.; WANG, M.; WANG, Q.; DIAO, X. An allthinfilm inorganic electrochromic device monolithically fabricated on flexible PET/ITO substrate by magnetron sputtering. Materials Letters, v. 142, p. 232-234, 2015.

8 ÁlVAREZ, Diego Alonso; LLIN, Lourdes Ferre; MELLOR, Alexander; PAUL, Douglas, J.; NICHOLAS, J.; DAUKES, Ekins. ITO and AZO films for low emissivity coatings in hybrid photovoltaic-thermal applications. Solar Energy, v. 155, p. 82-92, 2017.

${ }^{9}$ FATHI, M.; ABDERREZEK, M.; GRANA, P. Technical and economic assessment of cleaning protocol for photovoltaic power plants: Case of Algerian Sahara sites. Solar Energy, v. 147, p. 358-367, 2017.

10 FOUARD, M.; Shihata, L.; Morgan, E. An integrated review of factors influencing the performance of photovoltaic panels, 2017. 
${ }^{11}$ GHOLAMI, A.; SABOONCHI, A.; ALEMRAJABI, A. A. Experimental study of factors affecting dust accumulation and their effects on the transmission coefficient of glass for solar applications. Renewable Energy, v. 112, p. 466-473, 2017.

12 BOURAIOU, A.; HAMOUDA, M.; CHAKER, A.; LACHTAR, S.; NEÇAIBIA, A.; BOUTASSETA, N.; MOSTEFAOUI, M. Experimental evaluation of the performance and degradation of single crystalline silicon photovoltaic modules in the Saharan environment. Energy, v. 132, p. 22-30, 2017.

13 WANG, P.; XIE, J.; NI, L.; WAN, L.; OU, K.; ZHENG, L.; SUN, K. Reducing the effect of dust deposition on the generating efficiency of solar PV modules by superhydrophobic films. Solar Energy, v. 169, p. 277-283, 2018.

14 SAID, S. A. M.; HASSAN, G.; WALWIL, H. M.; Al AQEELI, N. The effect of environmental factors and dust accumulation on photovoltaic modules and dustaccumulation mitigation strategies. Renewable and Sustainable Energy

Reviews, v. 82, p. 743-760, 2018.

15 BRAGAGLIA, M.; LAMASTRA, F. R.; TULUI, M.; GASPARE, L.; NOTARGIACOMO, A.; VALENTINI, M.; NANNI, F. Low temperature sputtered ITO on glass and epoxy resin substrates: influence of process parameters and substrate roughness on morphological and electrical properties. Surfaces and Interfaces, 2019.

16 CHEN, Y.; LIU, Y.; TIAN, Z.; DONG, Y.; ZHOU, Y.; WANG, X.; WANG, D. Experimental Study on the Effect of Dust Deposition on Photovoltaic Panels. Energy Procedia, v. 158, p. 483-489, 2019.

17 DEMIRHAN, Y.; KOSEOGLU, H.; TURKOGLU, F.; UYANIK, Z.; OZDEMIR, M.; AYGUN, G.; OZYUZER, L. The Controllable Depositıon Of Large Area Roll-To-Roll Sputtered Ito Thın Fılms For Photovoltaıc Applıcatıons. Renewable Energy, 2019.

${ }^{18}$ LEI, T.; PENG, R.; HUANG, L.; SONG, W.; YAN, T.; ZHU, L. 13.5\% flexible organic solar cells achieved by robust composite ITO/PEDOT:PSS electrodes. Materials Today Energy, v. 14, 2019.

19 PINTO, G.; PLATA, G. Measuring factors influencing performance of rooftop PV panels in warm tropical climates. Solar Energy, v. 185, p. 112-123, 2019.

20 SAJJAD, U.; AMMER, M.; MUHAMMAD, A.; DASHIYA, A.; ABBAS, N. Cost effective cooling of photovoltaic modules to improve efficiency. Case Studies in Thermal Engineering, 2019.

21 SARKIN, A. S.; EKREN, N.; SAGLAM, Ş. A review of anti-reflection and selfcleaning coatings on photovoltaic panels. Solar Energy, v. 199, p. 63-73, 2020.

${ }^{22}$ LI, X.; LIU, T.; WANG, J.; XU, L.; ZHANG, Z. Dust Deposition can Focus Light at a Limited Distance on Photovoltaic Panels. Journal of Quantitative Spectroscopy and Radiative Transfer, 2020. 